\title{
Infectious adverse effects during treatment with IL-1 inhibitors in patients with systemic juvenile idiopathic arthritis and autoinflammatory diseases
}

\author{
Laura Fernandez-Silveira, M Isabel González-Fernández*, Berta López-Montesinos, Silvia Benito-Costey, \\ Inmaculada Calvo-Penadés
}

From 21st European Pediatric Rheumatology (PReS) Congress

Belgrade, Serbia. 17-21 September 2014

\section{Introduction}

IL-1 plays an important role in the pathogenesis of both illnesses. The anti-IL1 therapy (anakinra/ canakinumab) had been proved to be very effective in their treatment. The infections related to these treatments in children had been hardly described in literature.

\section{Objectives}

To describe the infectious complications in children with systemic juvenile idiopathic arthritis (SJIA) or autoinflammatory diseases $(\mathrm{AD})$ while receiving anti-IL1 drugs.

\section{Methods}

All the patients who had received IL1 inhibitors from January 2005 to January 2014 in our unit were included. We recorded the length of the exposition to anakinra or canakinumab, diagnosis, previous exposition to a different biologic treatment and moderate or severe infections.

The patients with SJIA were defined by the ILAR criteria. In the $A D$ group were included familiar mediterranean fever (FMF), Hiper IgD syndrome (HIDS), tumour necrosis factor receptor-associated periodic fever syndrome (TRAPS), Cryopyrin-Associated Periodic Syndrome (CAPS) and 1 pyogenic arthritis, pyoderma gangrenosum and acne syndrome (PAPA).

\section{Results}

Thirty nine patients were identified: 28 SJIAS and 11 AD (7 HIDS, 2 TRAPS, 1 PAPA, 1 CAPS). Sixteen of them had received canakinumab, 35 anakinra and 12 had received both consecutively. Their mean age were 8.7 years (IQR 4.4-13.2).

Pediatric Reumatology, Hospital la Fe, Valencia, Spain
At least one moderate-severe infection happened in 10/ 39 (25\%) patients. The mean period from the first dose to the first infection was 1.78 years (range $0.3-3.75$, IQR 1.05-2.65).

In the SJIA group 3/28 (10\%) of the patients had at least one outstanding infection with a total of 7 episodes. In the AD group 5/11 (45\%) developed at least one infection, with a total of 10 episodes, all of them in patients with HIDS. The $71 \%$ of patients with HIDS had at least one moderate-severe infection. Three patients accumulated the $52 \%$ of the episodes.

While receiving anakinra the infection rate was 11,6 episodes x 100 patients/year of treatment and 14, 4 while receiving canakinumab (RR 1.2). Table 1.

\section{Conclusion}

This study suggests a similar incidence of infections in both groups of treatment. Nevertheless we have observed a higher incidence of infections in the AD Group compared to the SJIA group.

\section{Table 1}

\begin{tabular}{|c|c|c|}
\hline & SJIA: 28 patients & AD: 11 patients \\
\hline \multirow[t]{3}{*}{ Canakinumab } & 1 pneumonia & 1 Herpes Zoster \\
\hline & & 1 Soft tissue infection \\
\hline & & $\begin{array}{l}1 \text { Recurrent low urinary tract } \\
\text { infection }\end{array}$ \\
\hline \multirow[t]{5}{*}{ Anakinra } & 4 pneumonia & 1 pneumonia \\
\hline & 1 HPV infection & 1 sepsis \\
\hline & $\begin{array}{l}1 \text { severe VEB } \\
\text { infection }\end{array}$ & 1 severe herpetic stomatitis \\
\hline & & $\begin{array}{l}1 \text { Recurrent low urinary tract } \\
\text { infection }\end{array}$ \\
\hline & & 2 oropharingeal candidiasis \\
\hline
\end{tabular}




\section{Disclosure of interest}

L. Fernandez-Silveira: none declared. M. GonzálezFernández: none declared. B. López-Montesinos: none declared. S. Benito-Costey: none declared. I. CalvoPenadés: grant / research support from Colaboration in clinical trials Novartis.

Published: 17 September 2014

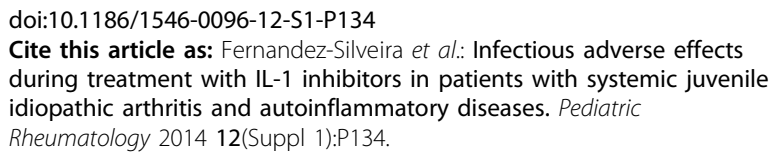

Submit your next manuscript to BioMed Central and take full advantage of:

- Convenient online submission

- Thorough peer review

- No space constraints or color figure charges

- Immediate publication on acceptance

- Inclusion in PubMed, CAS, Scopus and Google Scholar

- Research which is freely available for redistribution

Submit your manuscript at www.biomedcentral.com/submit 